\title{
Study on the General Music Education of Normal University
}

\author{
Chuanzhi Zhong \\ Department of music, Nanchang Normal University
}

Keywords: Normal University; General Music Education; Countermeasures for Present Situation.

\begin{abstract}
Music education, as an important sector of education for all-round development plays a vital role in the formation and development of students' comprehensive quality. In recent ten years, various colleges and universities have highlighted quality education and art education which provide guidance for non-music major students in terms of music, art, drama, dance etc and as a result, their comprehensive quality has been obviously improved. But on the whole, some colleges and universities don't have mature recognition, good teaching force, and perfect facilities so the art education is passive. For example, the teaching contents, course setting lack systematic implementation and the teaching technique lacks flexibility. This paper starts with various functions of music education so as to analyze the general music education of non-music major students in normal universities.
\end{abstract}

\section{Introduction}

The demand for high quality talent is the premise and foundation for development in various circles and education is the main channel to cultivate talents. Therefore, for normal universities, the bases for talents cultivation should pay attention to high-quality talents cultivation. Art education is an important part of quality education and music education is the most creative and representative form which has distinctive features and unique educational function throughout the entire educational system in normal universities.

In normal universities, the music major should be set. Yet, it should also be popular among all of the students. Just like Soviet educator Suhomlinski once said the target of carrying out music education is not cultivate musicians but cultivate harmonious relationship. Teachers are the soul engineers of people, who should possess abundant and professional knowledge, correct political direction, and healthy body but also correct aesthetic and noble taste, noble aesthetic temperament, rich spiritual world and good mental quality and so that they are able to take on the mission to be good examples. Cultivating high-quality talents with all-round development in terms of morality, intellectual, sport and beauty should be the ultimate goal of Normal universities. So, it is inevitable to set the music course. Besides, the basic music development in middle and primary schools is unbalanced (especially in rural and city schools) because most of schools blindly pursue the enrollment quotas which lead to the condition that students in colleges and universities have poor aesthetic skills in terms of music. So, we have to strengthen the music education and improve their aesthetic skills to promote their full development. Moreover, the vice-premier Li Lanqing clearly pointed out in Promoting Symphonic Music in Colleges and Universities on 19th November 1997 that the aesthetic function of music can not only improve their aesthetic judgment but also develop the intelligence. In addition, it can help to create the imaginative, creative ability and the ability to solve problems. Music has profound influence on the civilization of society. From this sentence, we 
can know that general music education in normal universities plays a vital role in the all around development of 21 st century and teachers play a link role and directly affect the realization of quality education.

Art education in recent ten years has achieved great achievements, and both the central government and regional government all highlight the importance of art education and music education. What's more, Standard of Music Full-time Compulsory Education Curriculum (for experiment) is issued and the art education committee is set up to make the document called Overall Plan for National Art Education from 1989 to 2000 which clearly points out that colleges and universities should extend the art literary class to carry out the art education. At present, the art education is booming and the national university student art show is a test for art education with unprecedented performance type, form, content and scale which fully elaborate that the art education of colleges and universities is marching toward a stable development stage. However, there inevitably will be new problems. The art education of colleges and universities is somewhat random and blind without clear teaching target, regulated teaching materials, and unified teaching methods. This paper comes up with advancement approach and countermeasures based on the recognition of music education function and the exploration on the current condition of music education in normal universities.

1. The status and function of general music education in quality education of normal universities

2. The present situation and existing problems of general music education of normal universities

3. Approaches and countermeasures to improve the general music education of normal universities

The development of general music education in quality education: it can be broadly divided into professional quality education, moral education, aesthetic education, psychological quality education etc. The education content of normal university is carried out based on above discussion because the moral, aesthetic education and psychological education are very important to cultivate students to teachers besides professional knowledge education. Besides, the comprehensive cultivation of moral, aesthetic and psychological education can help to strengthen the teaching ability because teachers face different students with unique characteristics and they cannot carry out effective education without solid professional knowledge. In addition, teachers cannot successfully communicate with students without good morality, correct aesthetic concepts and excellent psychological quality which cannot complete the aim of quality education.

Music as a branch of arts is developed along with the development of human civilization with a long history and rich content. It originates from labor to express thoughts and feelings of people, which is the most extensive and direct carrier to show emotion and express aesthetic appealing. What's more, as a cultural configuration of society, it has been widely adopted by various classes therefore it is closely related to political science, sociology, history, geography, ethics, religion, psychology, literature and other subjects. Obviously, music is not equal to quality education and we advocate quality education based on music which obeys the basic rules of music education. However, it is not wise to ignore the effect of music on quality education. Music education has been regarded as one of the most important contents of quality education all over the world, and China is no exception. From ancient times till now, a glittering array of thinkers and educators has penetrating elaboration on the significant meaning of music education: as far as Kong $\mathrm{Yu}$ concerned it is emerged along with poem, supported by etiquette and completed by music; Mencius once said the effect of music is better than right word. Besides, Master Xun said that music can affect people 
quickly. In addition, Liang Qichao said that poems and music are important to change the quality of citizens.

Music education has received more and more attention because it is important content of quality education and is also getting along swimmingly with other qualities.

Music is closely related to literature, history and other humanity subjects. In early times, poems and music are combined with each other. The first poetry collection in Chinese history is The Book of Odes which is actually the collection of temple and folk land songs during Shang and Zhou period; folk rhyme in Han dynasty is the title of music institutions as well as poem forms; afterwards, there are independent scholar poem separated from music such as spectrum lyrics in Song poetry, divertimento in Yuan Dynasty etc in poems. All of them are literature arts, which are combined into politics, history, culture as well as customs and they are organic components of music. Music singing is easy to memorize and spread. So, the music education can help to greatly expand the horizon of students and help them have a good understanding of politics, history, culture, religion, and customs in different regions and different periods which are beneficial to improve the cultural quality of students.

Music is non-semantic information and non-representational art. The free, fuzzy and uncertain characteristics provide a broad space for imagination and association. The creation, performance, and appreciation of music all reflect distinctive creative consciousness and unique creative behavior so music is the most creative art. These characteristics give a great space for imagination which provides good mental basis for the cultivation of divergent thinking and creative ability. Music with a unique form: music-imagination-fantasy-creation reveals the characteristics and relations of various matters and phenomena. The essential advantage of music education lies in the development of thinking ability and stimulating people's imagination. Music is related to education and can inspire the logical thinking ability and abstract thinking ability of learners. Modern physiology research shows that the human brain is divided into two parts. The left part possesses the functions of calculation, discussion and language while the right part ignites emotions and has functions of balance, image identification and imagery thinking. The full development of both these two parts along with coordination can help to achieve high intelligence. The appreciation, singing and performance of music can be regarded as effective means to stimulate emotions and develop thinking ability which can also coordinate to achieve harmony. Therefore, it can promote the development of the right and left brain to develop both the creative ability and logic ability. The appreciation and performance of classic modern and ancient music can evoke sympathy and rational intelligence to cause enthusiastic practice. This rational recognition is beyond phonetic symbol with profound recognition value and is helpful to master the knowledge of humanistic disciplines, cultural discipline and applied innovation so as to improve the learning quality and effect.

Darwin wrote in The Origin of Species that loss of music interests will lose happiness and even intelligence. He said that music makes me excited to think about the problems I am studying on. Einstein a great scientist often adopts music activities to inspire and develop their abstract thinking ability. He said, many of the inventions come from music inspiration. After obtaining remarkable achievements in science he concluded that imagination is more important than knowledge because knowledge is limited while imagination summarizes everything throughout the world and push the world to forward which is also the source of knowledge evolution. A famous Chinese scientist Qian Xuesen once carried out concrete and excellent analysis on the thinking process combining science and art. He said that judging from critical thinking, science starts from imagination and then the 
science test. In another word, scientific work comes from thinking and ends in logic thinking and imaginative thought originates from art so scientific worker starts art work and then science work. There are various thoughts in the course of music learning, especially in the course of imaginative thought application and development. The combination of imagination, image, and memory can help to improve the intelligence and develop creation ability so as to make the brain work better which can improve the professional quality of students.

Education is an activity to cultivate people and focuses on the business in the future. Its ultimate goal is to promote and realize the self-development of students and so is higher education. It spreads knowledge, and studies advanced knowledge so as to cultivate qualified talents to construct a better nation and society. Facing keen competition in 21 st century, the Party and government puts forward an idea to cultivate interdisciplinary talents. So, general education has become the mainstream of China's higher education reform. The general education in modern society should contain art education especially music education which is not only a theoretical problem, but also a practical problem. Music education plays an important role because it cultivates people's artistic quality as well as other qualities. Therefore, in modern higher education, we have to determine its rightful place to fully play its function and promote the all-round development of students. This paper sticks to the idea that the most pressing task is to strengthen the music education in normal universities which is determined by the current condition and objectives of basic education as well as the tasks normal universities take on.

After the Cultural Revolution being ended, we correct the erroneous left military line, criticize two whatever and fight against personality cult to get rid of modern superstitions. It aims to bring order out of chaos. However, after a dazzling array of political movements, especially after experiencing Cultural Revolution, people think that it is ridiculous to obey the political propaganda and they no longer have beliefs only trust themselves. Besides, the reform and opening up along with the introduction of advanced scientific and management approach, some decadent ideologies also come into people's mind, some people seek nothing but profits, worship money, take drugs and criminals etc. In the contrast, good morality activities become less and there is a decline of morality. At present, students are exposed to such environment. Besides, most of them are independent children who are spoiled without suffering obstacles and they may be defeated by little frustrations with mental diseases. Therefore, it is difficult to educate those who grow up under such environment. The quality education is clearly pointed out under such background and is widely accepted in the society.

We should emphasize that general music education should be implemented and strengthened in normal universities but it does not mean that we deny the significant meaning and positive effect of music education in other colleges and universities. At first, quality education is carried out because of basic education which should be extended to higher education. Practice has proved that general music education is an inevitable means to cultivate interdisciplinary talents and improve the quality of the new generation students. Normal universities are the talent bases for basic education and the cradles to cultivate qualified teachers. Even though, non-normal university students can also participate in the competition for being teachers and elites will also participating in the career of shaping the soul of human beings which is an inevitable trend in the talent market. However, the main source of basic education is normal universities, which is determined by the nature of schools and cultivation targets of education because only talents cultivated in normal universities can take on 
the task to implement basic education and this is an important sector of implementing strategy of invigorating the country through science.

The general music education as important part of aesthetic education in higher normal universities is also an important aspect for human construction. It is a humane subject to shape people from a comprehensive perspective which plays an important role in improving the quality of residents and talents. Ye Lang of Peking University pointed out that university education is not simple professional education and its target is not only to carry out professional training but to cultivate innovative talents with all-round development who possess high quality and healthy personality. On June 13 1999, the State Council promulgated the Decision on Deepening Education Reform and Promoting Quality Education which clearly points out that colleges and universities should ask students to select classes (including arts). Action Plan for Invigorating Education during 2003 to 2007 issued by Ministry of education points out that strengthening the aesthetic education has become an inevitable requirement for the economic development in 21 st century and is the objective requirement for the development in 21st century. However, in a long period, there are many problems in normal university music education because of people's ideas, society and family education.

The general music education in colleges and universities started in 1950s. Because of historical reasons, it is interrupted from time to time which was recovered in the beginning of 1980s. Some famous universities, such as Qinghua University, Shanghai Jiaotong University, Shenyang Institute of Aviation, and universities in Beijing started to set the music department in 1980s. According to the survey, only two-thirds colleges and universities set artistic courses at the end of 1995, and the contents are enriched from single music appreciation to music knowledge, appreciation and practice with more than 10 type materials. However, the music education is spontaneous behavior promoted by several universities and some colleges and universities do not take it into consideration. Therefore, music education does not shine out without good effect.

Fuzzy understanding and deviated positioning

The role of general music education is not paid attention to in normal universities

There are also general problems of general music education in normal universities

Unreasonable course setting

Irregular teaching materials

Incomplete teaching facilities

Imperfect faculties

Now, a new round basic education reform has started and the education teaching reform wins support among the people and people's ideas have been gradually changing. Normal universities cannot lag behind in terms of cultivating all-round, high quality and innovative talents. Then what should we do to solve the existing problems to carry out deep teaching reform and achieve the teaching goals?

Transform teaching philosophy, accelerate the teaching reform

Relevant leaders (departments) should emphasize and promote aesthetic education legislation

Write comprehensive and scientific teaching materials

Improve the quality of teachers and guarantee the teaching quality

Strengthen the efforts to carry out music education reform

Perfect the institution construction and enliven extracurricular activities 


\section{Conclusions}

General music education in normal universities started in 1980s, which is in an exploring stage. The general music education develops toward a standardized and scientific direction and it will be open, flexible, diversified, and dynamic in the future. With the deepening reform of education, rapid development of high technology, the general music education helps to fully play its function such as developing imagination, improving the adaptive ability and comprehensive quality. In addition, music education plays a complementary effect in terms of music education reference and coordinated development. Therefore, in the teaching mission facing modernization, world and the future, it will be greatly developed in 21 st century. I hope faculties and students shall try the utmost to develop the general music education.

It is imperative to promote the music education in normal universities but it cannot be accomplished by one step. Based on the real condition, we can flexibly apply the effective experience to teaching work so as to promote the formation and perfection of the music education setting, which is feasible. Music teaching in normal universities should meet the needs of $21 \mathrm{st}$ century so as to strengthen the rational thinking ability and adaptive abilities of students and improve their innovative ability and logic thinking. We expect that general music education in normal universities can help to cultivate all-round developed talents and play a more significant role.

\section{References}

[1]Li Lanqing. Promoting Symphonic Music in Normal Universities. People's Music, 998,(3).

[2]Li Tingtao, Li Yiming. Music Education in Colleges and Universities in China. Music Education Press, 2002

[3]Li Min, Du Guang. Principle and Method of Music Education. Hunan Education Press, 1998

[4]Cao Li. Music Education. Capital Normal University Press, 2000.

[5]Wu Yueyue. Synergy Theory for Music Education and Quality Training. Hunan Education Press, 1999

[6]Cao Li, He Gong. Music Learning and Teaching Psychology. Shanghai Music Publishing House, 1998

[7]Wei Chuanyi. Art Education. Chongqing Publishing House, 1990

[8]Li Manli. General Education- A View of University Education. Tsinghua University Press, Sep.1999; Guo Shengjian. Art Education Theory. Shanghai Education Publishing House, 2001

[9]Peng Jixiang. Art Study Introduction. Peking University Press, 1994 